\title{
Sistem Pemantauan Nirkabel dan Real Time Kualitas Air Sungai Muara Lembu Kuantan Singingi
}

\author{
Yusnita Rahayu*, Dian Yayan Sukma, Nurhalim \\ Universitas Riau \\ yusnita.rahayu@lecturer.unri.ac.id
}

\begin{abstract}
Abstrak
Pencemaran lingkungan yang diakibatkan oleh pembuangan limbah cair pabrik kelapa sawit dapat menyebabkan ketidakseimbangan ekosistem. Tidak hanya bagi tumbuhan, dan hewan, namun pengaruh pencemaran tersebut menyebabkan gangguan kesehatan masyarakat sekitar. Kegiatan abdimas ini dilakukan di Desa Sungai Bawang tepatnya pada aliran sungai Muara Lembu. Untuk pemantauan kualitas mutu air, penulis merancang bangun sistem pemantauan berbasis nirkabel dan real time. Parameter berupa kekeruhan dan $\mathrm{pH}$ menjadi prioritas pengamatan untuk kegiatan abdimas ini. Bacaan kedua sensor ditampilkan pada papan informasi yang dibangun di depan kantor desa, untuk memudahkan aparatur dan masyarakat sekitar mengawasi kualitas mutu air sungai. Dari hasil pengamatan, air sungai bersifat asam karena mengandung $\mathrm{pH}$ berkisar 5,4-5,9, sementara untuk kadar kekeruhan pada tahap sedang dengan nilai berada di antara 125-205 NTU.
\end{abstract}

Kata Kunci: limbah sawit, pemantauan mutu air, sensor

\section{Wireless and Real Time Monitoring System for Muara Lembu Kuantan Singingi River Water Quality}

\begin{abstract}
Environmental pollution caused by the liquid disposal of palm oil mill can cause an imbalance to the ecosystem. Not only for plants and animals, but the effect of this pollution causes health problems for the surrounding community. This community service was carried out in Sungai Bawang Village to be precise at the Muara Lembu river. To monitor water quality, the authors designed a wireless and real time based monitoring system. Parameters in the form of turbidity and $\mathrm{pH}$ are priority observations for this activity. The reading of the two sensors is displayed on an information board built in front of the village office, to make it easier for officials and the surrounding community to monitor the quality of river water. From the results of the observations, river water is acidic because it contains a pH ranging from 5.4 to 5.9, while the turbidity level is at a moderate stage with a value between 125 - 205 NTU.
\end{abstract}

Keywords: palm oil waste, water quality monitoring, sensor

\section{PENDAHULUAN}

Desa sungai bawang merupakan sebuah desa yang terletak di kecamatan Singingi, Kuantan Singingi, Riau, Indonesia. Desa ini terletak di sebelah Timur kota Pekanbaru dengan jarak 141,6 km, sebelah utara berbatasan dengan Desa Sungai Sirih, sebelah selatan dengan Desa Logas Hilir, sebelah timur dengan Air Emas, sebelah barat dengan Desa Muara Lembu. Jarak Desa Sungai Bawang ke ibukota kecamatan terdekat $30 \mathrm{~km}$. Jarak Desa Sungai Bawang ke ibukota kabupaten adalah $30 \mathrm{~km}$. Lama jarak tempuh Desa Sungai Bawang ke ibukota terdekat adalah 60 menit. 
Masyarakat Desa Sungai Bawang mayoritas bekerja sebagai petani kelapa sawit. Desa Sungai Bawang merupakan desa yang berpotensi besar dalam perkebunan kelapa sawitnya, ditambahkan lagi dengan berdirinya pabrik kelapa sawit di daerah tersebut sehingga sedikit banyaknya membangkitkan minat masyarakat dalam perkebunan kelapa sawit. PT X adalah satu-satunya pabrik yang memproduksi minyak kelapa sawit yang berada di Desa Sungai Bawang Kecamatan Singingi Provinsi Riau.

Pabrik kelapa sawit adalah tempat pengolahan buah kelapa sawit mulai dari proses pemanenan hingga akhirnya diolah menjadi minyak kelapa sawit yang banyak digunakan oleh manusia. Pengolahan minyak kelapa sawit di Indonesia telah menjadi salah satu yang terbesar di dunia sejak puluhan dan bahkan ratusan tahun silam. Alasan utamanya ialah kualitas dari kualitas kelapa sawit di Indonesia terbukti sangat unggul sehingga dapat menghasilkan minyak kelapa sawit dengan kualitas yang telah diakui oleh dunia internasional. Di beberapa pulau di Indonesia seperti Sumatera dan Kalimantan, telah banyak terdapat pabrik minyak kelapa sawit yang memiliki omzet yang sangat besar. Riau merupakan salah satu daerah yang memproduksi minyak kelapa sawit terbesar.

Namun demikian akibat berdirinya pabrik kelapa sawit tersebut telah menimbulkan dampak pencemaran limbah terhadap sungai yang berada di Desa Sungai Bawang, salah satunya adalah sungai Muara Lembu. Selama ini pembuangan limbah sawit hasil produksi PT X dibuang ke aliran Sungai Muara lembu. Hal ini yang melatarbelakangi penulis mengangkat masalah ini sebagai kegiatan abdimas. Masalah yang terjadi pada tahun 2018 yang dipublikasikan pada goriau.com, di mana limbah dari pabrik sawit mengalami kebocoran yang mengakibatkan sungai muara lembu mengalami pencemaran dan mengakibatkan terganggunya ekosistem. Hal ini tentu menghambat fungsi sungai yang mana dapat dimanfaatkan oleh masyarakat desa menjadi tidak bisa bermanfaat sama sekali karena pengaruh limbah. Padahal dengan adanya sungai yang mengalir di Desa Sungai Bawang masyarakat dapat memanfaatkan sumber daya alam (SDA) tersebut untuk meningkatkan pendapatan ekonomi seperti pemanfaatan sungai untuk tambak ikan dan tambak udang.

Limbah adalah buangan yang dihasilkan dari suatu proses produksi baik industri maupun domestik (rumah tangga). Bila ditinjau secara kimiawi, limbah ini terdiri dari bahan kimia senyawa organik dan anorganik. Dengan konsentrasi dan kuantitas tertentu, kehadiran limbah dapat berdampak negatif terhadap lingkungan terutama bagi kesehatan manusia, sehingga perlu dilakukan penanganan terhadap limbah. Tingkat bahaya keracunan yang ditimbulkan oleh limbah tergantung pada jenis dan karakteristik limbah. Hampir seluruh air buangan Pabrik Kelapa Sawit (PKS) mengandung bahan organik yang dapat menyebabkan degradasi kualitas air dan pencemaran (Kamal, 2014).

Sewaktu kunjungan penulis ke desa, penulis menerima banyaknya masyarakat yang mengeluh tentang air limbah sawit PT X yang dibuang di aliran sungai. Menurut penulis, hal ini dapat diatasi dengan memberikan sosialisasi ke masyarakat tentang bahaya limbah sawit dan penggunaan alat monitoring berupa Indeks Standar Pencemaran Air. Sosialisasi ini bertujuan untuk meningkatkan kepedulian masyarakat sekitar terhadap lingkungan. Peralatan monitoring berupa Indeks Standar Pencemaran Air sungai melalui $\mathrm{pH}$ dan kekeruhan Air Sungai dipasang pada aliran sungai yang terdampak, dan papan informasinya didirikan di depan kantor desa. Informasi dikirimkan oleh sensor di aliran sungai secara berkala dan real time 
Vol. 1, No. 3,

November

2020

pp. 116-125

e-ISSN:

2722-2004

\section{Title}

Wireless and Real Time Monitoring System for Muara

Lembu Kuantan

Singingi River

Water Quality

Author

Y. Rahayu,

D. Y. Sukma,

Nurhalim

sehingga memudahkan aparatur dan masyarakat desa untuk memantau kondisi kualitas air terkini.

Berdasarkan paparan di atas, kegiatan abdimas dilakukan dalam beberapa kegiatan yaitu rancang bangun sistem peralatan monitoring limbah, pemasangan sistem di aliran sungai dan di kantor kepala desa dan sosialisasi kepada masyarakat, agar masyarakat dapat melihat tingkat pencemaran sungai berdasarkan $\mathrm{pH}$ dan kekeruhannya. Hal ini tentu juga diharapkan menjadi perhatian bagi pengolah pabrik kelapa sawit agar masalah pencemaran sungai ini dapat teratasi dengan membuat sistem bak penampungan limbah yang lebih baik. Metode penerapan dan tingkat ketercapaiannya akan dijelaskan pada bagian di bawah ini.

\section{METODE PELAKSANAAN}

Pelaksanaan kegiatan abdimas ini dilakukan pada Agustus 2020. Lokasi kegiatan terletak di Desa Sungai Bawang Kecamatan Singingi (Gambar 1). Penentuan lokasi kegiatan abdimas ini berdasarkan masalah pencemaran limbah sawit yang pernah terjadi pada tahun 2018 dan letak geografis yang masih berada di Provinsi Riau. Untuk kegiatan perancangan sistem pemantauan dilakukan di laboratorium Dasar Teknik Elektro, Universitas Riau. Hal ini disebabkan karena alat harus dirancang dan diuji menggunakan instrumen laboratorium sebelum dipasang di tempat pengujian.
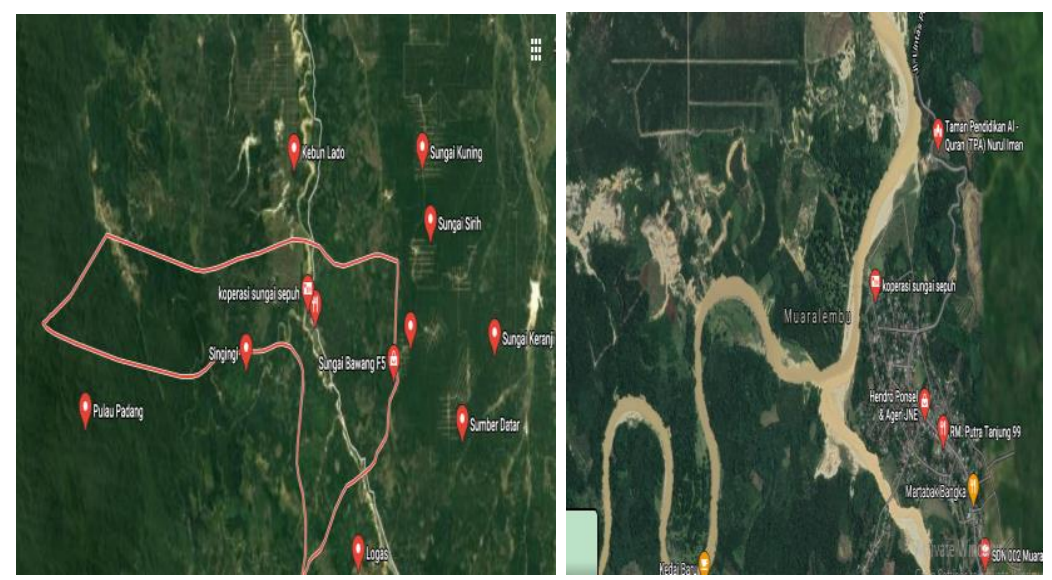

Gambar 1. Peta Lokasi Kegiatan Abdimas

Gambar 1 menunjukkan peta lokasi kegiatan abdimas di Desa Sungai Bawang, Kuantan Singingi yang terletak antara $0^{\circ} 00-1^{\circ} 00$ LS dan $101^{\circ} 02$ $101^{0} 55$ BT. Parameter yang diamati dan diukur ada 2 parameter sesuai dengan jumlah sensor yang digunakan yaitu $\mathrm{pH}$ dan kekeruhan. Analisis kualitas air dengan menggunakan metode indeks pencemaran menurut Keputusan Menteri Lingkungan Hidup No 115/2003 Lampiran II tentang penentuan status mutu air, untuk mengetahui tingkat pencemaran sungai dengan menggunakan rumus sebagai berikut:

$$
P i j=\sqrt{\frac{\left(\frac{C i}{L i j}\right)^{2} M+\left(\frac{C i}{L i j}\right)^{2} R}{2}}
$$


KANGMAS: Karya Ilmiah Pengabdian Masyarakat, 1 (3), November 2020 - 119

http://journal.neolectura.com/index.php/Kangmas

Di mana:

$\mathrm{Pij}=$ indeks pencemaran bagi peruntukan $\mathrm{j}$

$\mathrm{Ci}=$ konsentrasi parameter kualitas air di lapangan

$\mathrm{Lij}=$ konsentrasi parameter kualitas air i yang tercantum dalam baku peruntukkan air $\mathrm{j}$

$\mathrm{M}=$ Maksimum

$\mathrm{R}=$ Rerata

Kelas indeks pencemaran ada 4 yaitu:

Skor $0 \leq$ Pij $\leq 1,0$

Skor $1,0<$ Pij $\leq 5,0$

Baik (good)

Skor $5,0<$ Pij $\leq 10$

Skor Pij $>10$

Tercemar ringan (slightly polluted)

Tercemar sedang (fairly polluted)

Tercemar berat (heavily olluted)

Perancangan sistem pemantauan limbah yang terdiri dari sensor $\mathrm{pH}$ meter dan sensor turbidity menggunakan modul GSM dan ardruino mega untuk komunikasi data. Alat pemantauan ini ditempatkan pada aliran sungai Muara Lembu yang berdekatan dengan pembuangan limbah PT X. Hasil bacaan sensor yang didapat kemudian dikirim menggunakan modul GSM dan ditampilkan pada papan informasi yang didirikan di depan kantor desa seperti yang ditunjukkan pada gambar 2. Blok diagram alat pemantauan dapat dilihat pada gambar di bawah ini:

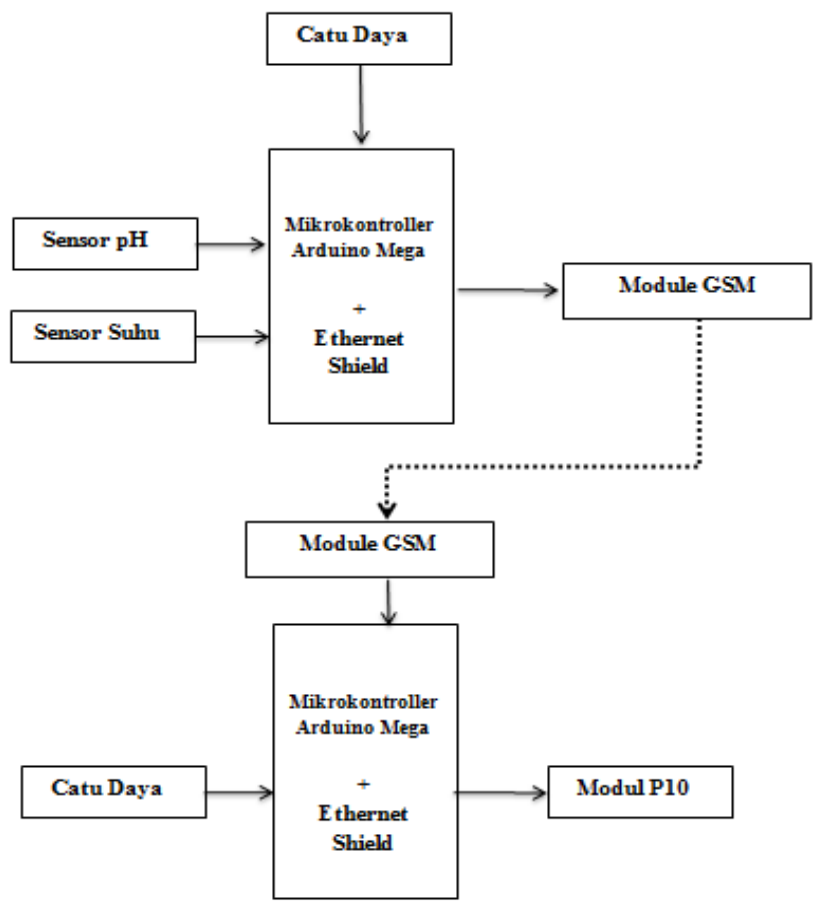

Gambar 2. Blok Diagram Alat Pemantauan Limbah Sawit

Gambar 2 menunjukkan blok diagram alat pemantauan limbah yang terdiri dari perangkat pemantauan di aliran sungai dan alat penerima data di papan informasi di kantor desa. Khusus catu daya pada alat pemantauan di sungai menggunakan baterai litium karena tidak tersedianya sumber arus listrik.

Papan informasi digunakan untuk menampilkan data $\mathrm{pH}$ dan kekeruhan agar memudahkan masyarakat untuk mengawasi pembuangan limbah kelapa sawit masih layak atau perlu dilakukan penanganan lebih lanjut agar tidak terjadi lagi peristiwa 
Vol. 1, No. 3,

November

2020

pp. 116-125

e-ISSN:

2722-2004

Title

Wireless and Real Time Monitoring System for Muara Lembu Kuantan

Singingi River

Water Quality

\section{Author}

Y. Rahayu,

D. Y. Sukma, Nurhalim

pencemaran limbah kelapa sawit yang merugikan masyarakat dan lingkungan yang terpapar oleh limbah tersebut.

Pendirian papan informasi di depan kantor desa Sungai Bawang dikarenakan letak kantor desa yang berada di tengah-tengah pemukiman masyarakat sehingga memudahkan masyarakat melihat dan membacanya.

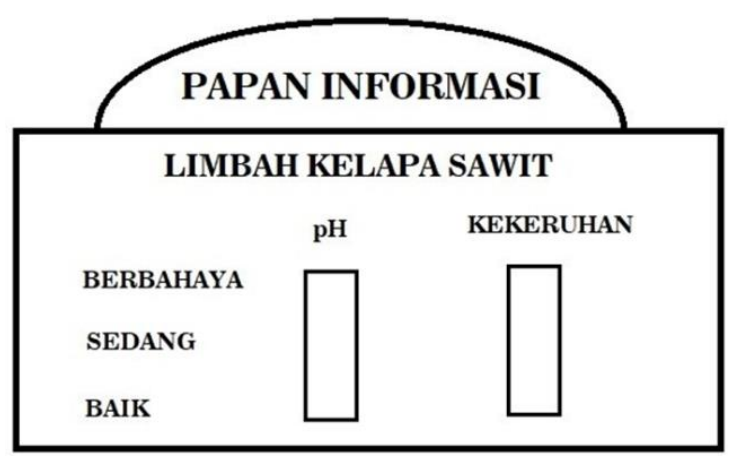

Gambar 3. Desain Papan Informasi

Gambar 3 menunjukkan bentuk tampilan dari papan informasi, Informasi pada papan terlihat bacaan kedua sensor dan tingkatannya, sehingga memudahkan masyarakat membacanya.

Pada tahap instalasi kedua alat pemantauan, beberapa aspek lapangan menjadi bahan pertimbangan yaitu peletakan alat pemantauan di sungai dan jarak dengan kantor desa. Hal ini dipertimbangkan untuk memastikan sistem dapat berfungsi dengan baik dan mengirimkan data secara berkala. Jarak dari aliran sungai tempat pemasangan alat sensor dengan papan informasi di kantor desa sejauh $1,5 \mathrm{~km}$. Alat pemantauan sensor diletakkan dalam sebuah kotak akrilik dan bagian luarnya dilapisi dengan kotak pelat besi yang tertutup rapat agar air tidak mudah masuk, kemudian kedua sensor tersebut terhubung dengan pipa PVC. Pipa PVC didesain seperti huruf "L" untuk menopang alat dan sekaligus mengalirkan air sungai agar sensor dapat membacanya. Kemudian pipa PVC tersebut ditanam di tanah dengan kedalaman $50 \mathrm{~cm}$ untuk memperkuat fondasi.

Gambar 4 adalah gambar pemasangan alat pemantauan sensor dengan pipa PVC. Terlihat pada gambar, bahwa pipa PVC dirancang berbentuk L sebagai penopang kotak alat dan mengalirkan air sungai ke dalam pipa.

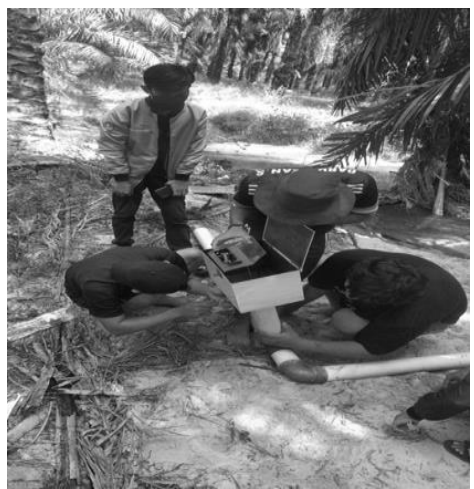

Gambar 4. Pemasangan Alat Pemantauan dan Pipa PVC di Aliran Sungai

Untuk membantu aparatur desa memahami makna dan maksud dari papan informasi tersebut, sosialisasi dilakukan kepada aparatur Desa Sungai Bawan yang 
KANGMAS: Karya Ilmiah Pengabdian Masyarakat, 1 (3), November 2020 - 121 http://journal.neolectura.com/index.php/Kangmas

kegiatannya dilakukan di kantor Desa. Kegiatan sosialisasi dilakukan dua kali yaitu terhadap aparatur dan terhadap masyarakat.

\section{HASIL DAN PEMBAHASAN}

\section{Hasil}

Pengujian sistem pemantauan limbah pembuangan sawit sudah berhasil dilaksanakan dan terpasang di Desa Sungai Bawang. Gambar 5 menunjukkan alat pemantauan beserta skema rangkaian elektronik yang digunakan. Alat pemantauan ini mampu mengirim dan menerima hasil pembacaan sensor $\mathrm{pH}$ dan kekeruhan air melalui modul GSM. Data sensor yang dikirimkan oleh modul GSM akan diterima pada mikrokontroller arduino dan ditampilkan pada papan informasi berupa running text dengan parameter $\mathrm{pH}$ dan kekeruhan dalam level rendah, sedang dan berbahaya seperti yang ditunjukkan pada gambar 6. Pada gambar 6 merupakan proses pengujian dan tampilan hasil bacaan real time sensor di papan informasi di kantor desa. Pengujian alat ini dilakukan secara langsung di desa selama seminggu, dari hasil pantauan alat mampu bekerja dengan baik menampilkan bacaan sensor secara berkala.

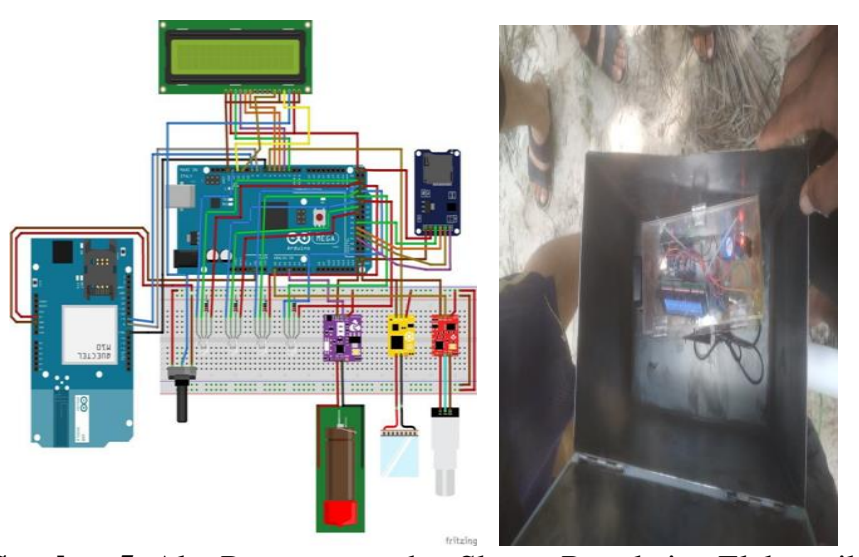

Gambar 5. Alat Pemantauan dan Skema Rangkaian Elektronik

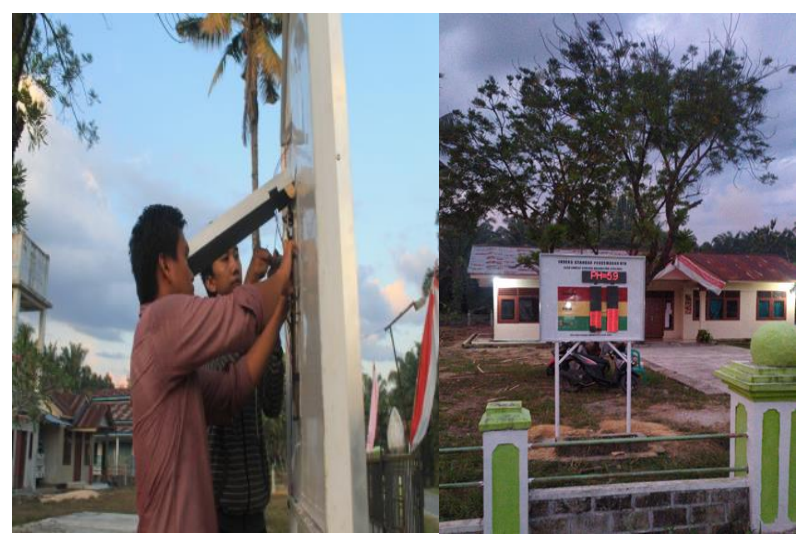

Gambar 6. Proses Pengujian dan Tampilan Hasil Bacaan Sensor Sistem Pemantauan 
Vol. 1, No. 3,

November 2020

pp. 116-125 e-ISSN:

2722-2004

\section{Title}

Wireless and Real Time Monitoring System for Muara

Lembu Kuantan

Singingi River

Water Quality

Author

Y. Rahayu,

D. Y. Sukma,

Nurhalim
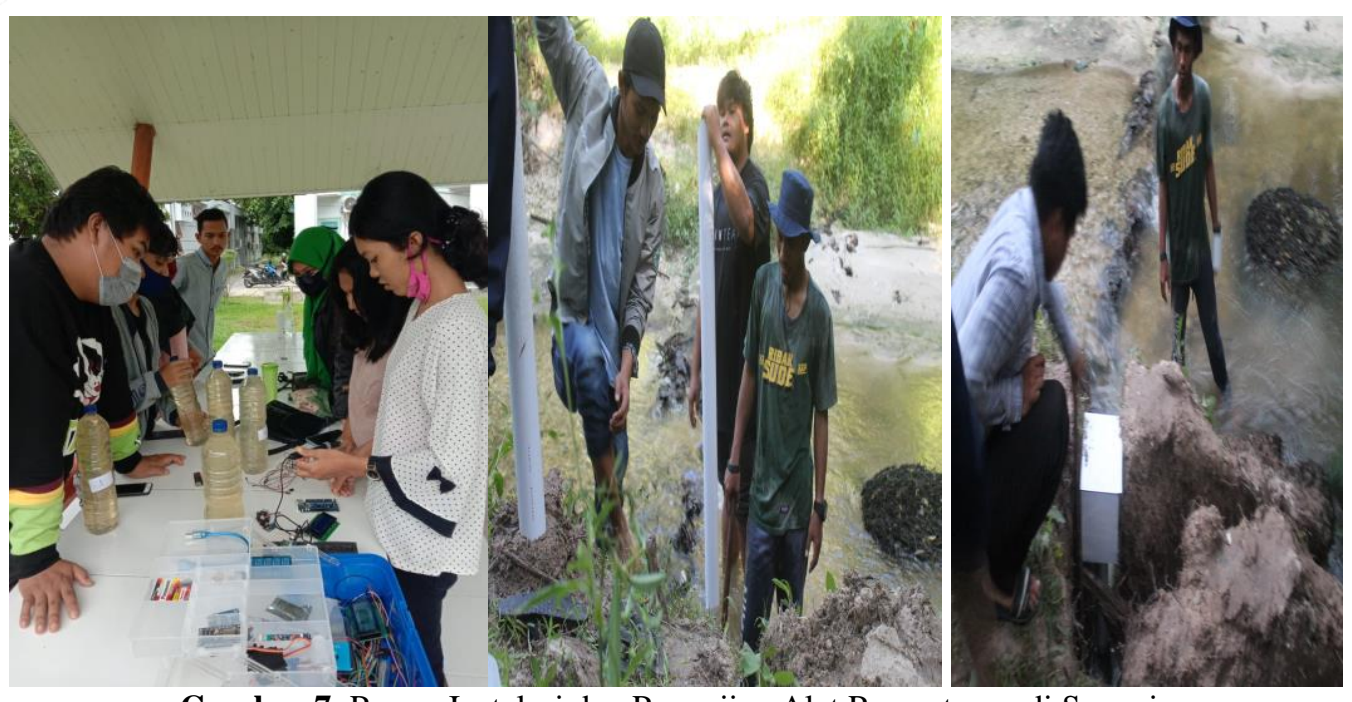

Gambar 7. Proses Instalasi dan Pengujian Alat Pemantauan di Sungai

Gambar 7 merupakan kegiatan instalasi pipa PVC dan pengujian alat pemantauan di sungai. Sebelum pengujian dilakukan di sungai, setiap komponen diuji menggunakan sampel air limbah untuk memastikan komponen berfungsi dengan baik.

Sosialisasi kepada masyarakat dilakukan untuk meningkatkan kepedulian masyarakat terhadap lingkungan sekitar. Alat ukur ketercapaian kegiatan sosialisasi ini yaitu diukur dari jumlah warga yang hadir mengikuti kegiatan sosialisasi program kerja dan sambutan warga yang ramah dan terbuka dengan kedatangan tim abdimas serta ketertarikan warga dengan program yang akan dilaksanakan juga tingkat pemahaman masyarakat terhadap materi kebersihan maupun tata cara membaca papan informasi.

Gambar 8 menunjukkan tim abdimas sedang melaksanakan sosialisasi kepada aparatur desa di kantor desa.

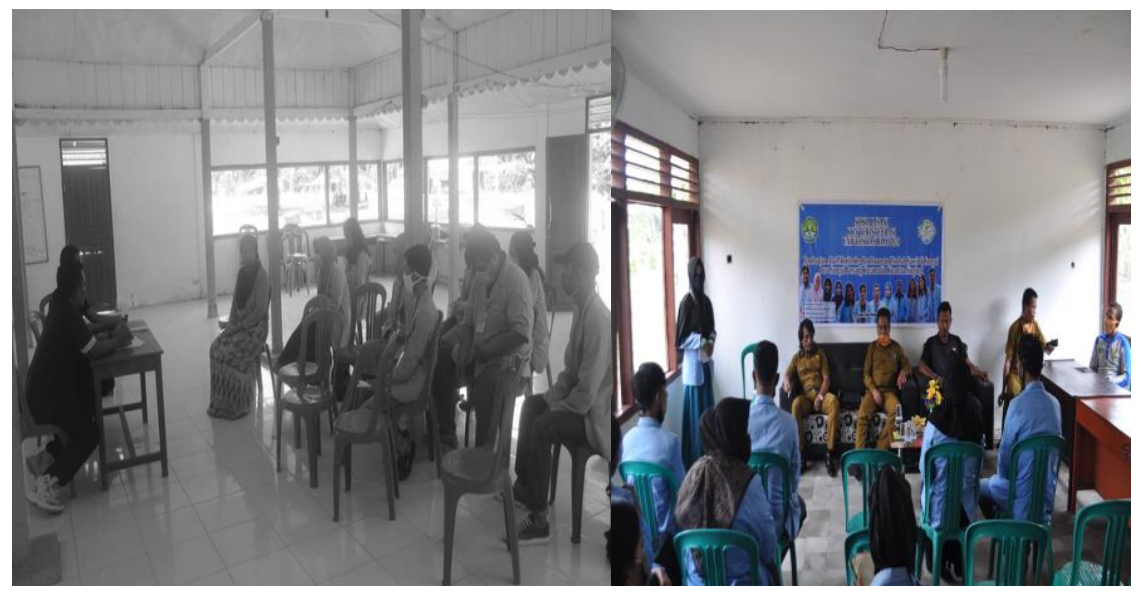

Gambar 8. Sosialisasi Kepada Aparatur Desa 
KANGMAS: Karya Ilmiah Pengabdian Masyarakat, 1 (3), November 2020 - 123

\section{Pembahasan}

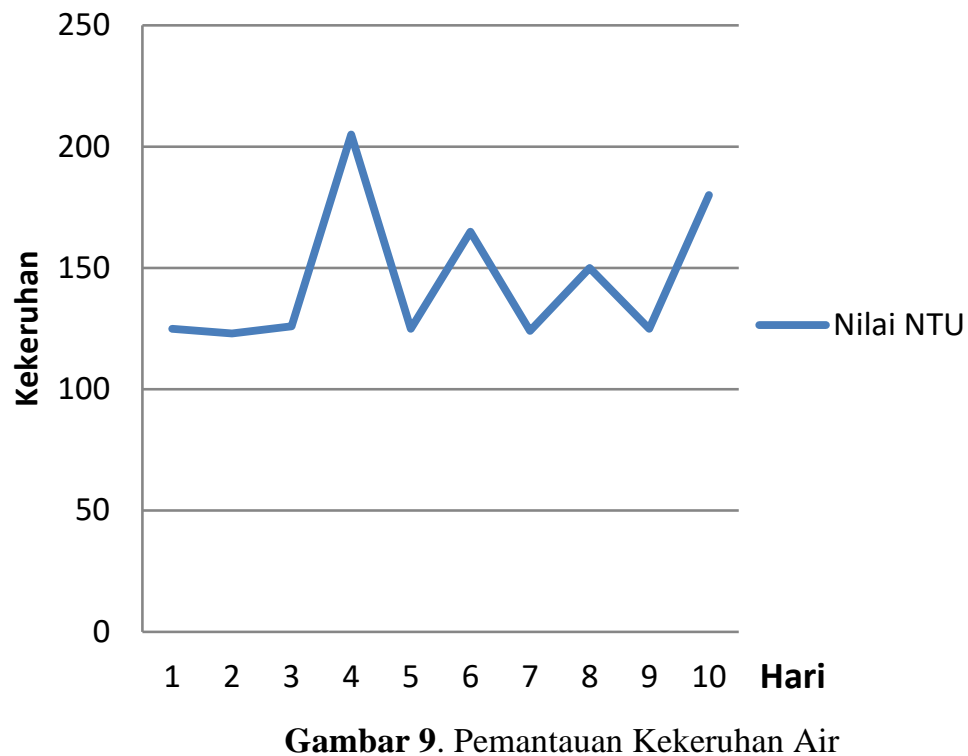

KANGMAS is a journal published by Neolectura, issued three times in one year. KANGMAS is a scientific publication media in the form of conceptual paper and field research related to social service work.

It is hoped that KANGMAS can become a media for academics and researchers to publish their social service work and become a reference source for the development of social and humanity.

Salah satu akibat negatif limbah pada air adalah kekeruhan dan perubahan $\mathrm{pH}$. Kekeruhan merupakan kondisi air, di mana air mengandung materi tersuspensi atau terlarut yang dapat menghalangi masuknya cahaya matahari sehingga jarak pandang dalam air menjadi terbatas (untuk melihat kedalaman air yang makin dalam akan sulit). Materi tersuspensi tersebut memiliki variasi ukuran, mulai dari yang berukuran koloidal hingga yang berukuran agregat kasar. Di mana, semakin besar total suspended solids yang terdapat dalam air maka akan semakin besar turbiditasnya ini (Effendi, 2003). Kekeruhan merupakan salah satu parameter fisika yang diukur dalam kegiatan abdimas ini.

Nilai kekeruhan air di Sungai Muara Lembu berkisar antara 125 - 205 NTU. Sebagai acuan, nilai ambang NTU air berada $>250$, ini menandakan bahwa air dalam keadaan berbahaya. Bila NTU 101-250, keadaan air masuk ke dalam kategori sedang, dan tergolong aman bila NTU 0-100. Dari hasil pengamatan yang dilakukan selama 10 hari, nilai kekeruhan dalam tingkatan sedang, hal ini disebabkan karena debit air pada saat pengujian dilakukan tidak terlalu banyak, karena tidak ada hujan dalam beberapa hari saat pengujian. Pengambilan sampel data hanya dilakukan selama 10 hari disebabkan karena situasi pandemi Corona dan pembatasan keluar masuk daerah yang diberlakukan oleh pemerintah daerah setempat.

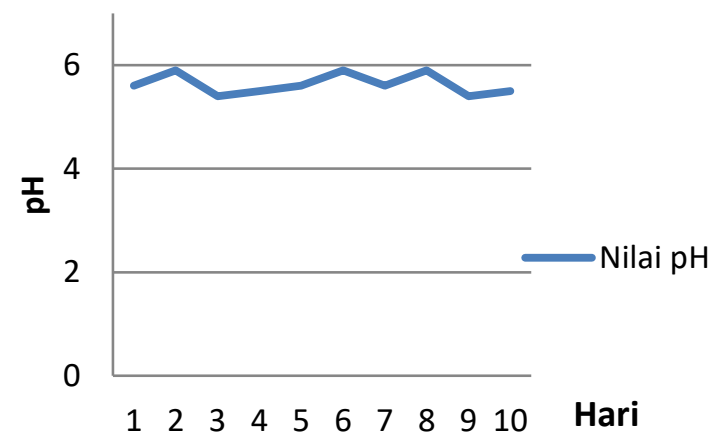

Gambar 10. Pemantauan Nilai pH Air 
Vol. 1, No. 3,

November

2020

pp. $116-125$

e-ISSN:

2722-2004

Title

Wireless and Real

Time Monitoring

System for Muara

Lembu Kuantan

Singingi River

Water Quality

Author

Y. Rahayu,

D. Y. Sukma,

Nurhalim

Asam dan Basa atau $\mathrm{pH}$ dan derajat keasaman digunakan untuk menyatakan tingkat keasaman atau basa yang dimiliki oleh suatu zat, larutan atau benda dengan skala 0 sampai 14. $\mathrm{pH}$ didefinisikan sebagai logaritma negatif aktivitas ion hidrogen (H+) yang terlarut (Blackstock, James C., 1989). Koefisien aktivitas ion hidrogen tidak dapat diukur secara eksperimental, sehingga nilainya didasarkan pada perhitungan teoritis. Skala $\mathrm{pH}$ bukanlah skala absolut, tetapi bersifat relatif terhadap sekumpulan larutan standar yang $\mathrm{pH}$-nya ditentukan berdasarkan persetujuan internasional

Konsentrasi $\mathrm{pH}$ air di Sungai Muara Lembu berkisar 5,4-5,9. $\mathrm{pH}$ adalah salah satu faktor terpenting yang melayani indeks untuk polusi. $\mathrm{pH}$ memiliki efek langsung pada kehidupan di ekosistem. Nilai ini mengindikasikan bahwa air Sungai Muara Lembu bersifat asam. Air akan bersifat asam atau basa tergantung besar kecilnya $\mathrm{pH}$. Nilai $\mathrm{pH}$ jika di bawah $\mathrm{pH}$ normal bersifat asam, sedangkan air yang mempunyai $\mathrm{pH}$ di atas $\mathrm{pH}$ normal bersifat basa. Air limbah dan bahan buangan industri akan mengubah $\mathrm{pH}$ air yang akhirnya akan mengganggu kehidupan organisme di dalam air (Enda Kartika S \& Oki Endrata W, 2019).

\section{SIMPULAN}

Pelaksanaan kegiatan abdimas ini telah berhasil dilakukan dan memenuhi tujuan yang diharapkan. Sistem pemantauan ini telah mampu membaca dengan baik kadar $\mathrm{pH}$ air dan tingkat kekeruhan secara real time sehingga memudahkan aparatur desa dan masyarakat sekitar memantau hasil bacaan sensor. Hasil data sensor yang dikirim menggunakan modul GSM dapat diterima oleh modul GSM yang berada dikantor desa Sungai Bawang. Pada saat pengujian dilakukan, nilai yang didapatkan pada pembacaan sensor $\mathrm{pH}$ pada rentang 5,4-5,9 dan tingkat kekeruhan antara 125-205 NTU, nilai tersebut mengindikasikan air bersifat asam dan kekeruhan termasuk ke dalam parameter tingkat sedang. Hal ini perlu menjadi perhatian bagi aparatur desa dan masyarakat agar pencemaran yang dulu pernah terjadi tidak terulang kembali. Sosialisasi kepada masyarakat dengan bertatap muka langsung terhadap pentingnya pengawasan masyarakat terhadap sistem pembuangan limbah cair kelapa sawit telah dilakukan, dan telah meningkatkan kepedulian masyarakat terhadap lingkungannya.

\section{UCAPAN TERIMA KASIH}

Penulis mengucapkan terima kasih kepada LPPM Universitas Riau yang telah mendanai kegiatan abdimas ini, sehingga kegiatan ini dapat bermanfaat bagi masyarakat Desa Sungai Bawang dan merupakan salah satu kegiatan Tri Darma Perguruan Tinggi. Terima kasih juga penulis sampaikan kepada Kepala Desa dan jajarannya atas kerja sama yang baik serta fasilitas yang diberikan selama tim abdimas berada di desa. Penulis juga mengucapkan terima kasih kepada tim mahasiswa kukerta Unri atas kekompakan dan kerja samanya sehingga tim abdimas dapat menyelesaikan seluruh kegiatan abdimas yang telah direncanakan. 
KANGMAS: Karya Ilmiah Pengabdian Masyarakat, 1 (3), November 2020 - 125 http://journal.neolectura.com/index.php/Kangmas

\section{DAFTAR PUSTAKA}

Admin. (2018, 17 November). PT SUN Akui Cemari Sungai Bawang Kuansing. Goriau.com. Diakses pada 2 November 2020, dari https://www.goriau.com/berita/baca/pt-sun-akui-cemari-sungai-bawangkuansing.html

Blackstock, James C. (1989). Guide to Biochemistry. London: Boston;Wright

Effendi, H. (2003). Telaah Kualitas Air bagi Pengelolaan Sumberdaya dan Lingkungan Perairan. Yogyakarta: Kanisius

Enda Kartika S \& Oki Endrata W. (2019). Penentuan Status Mutu Air dengan Metode Indeks Pencemaran dan Strategi Pengendalian Pencemaran Sungai Ogan Kabupaten Ogan Komering Ulu. Jurnal Ilmu Lingkungan, 17(3). 486491.

Kamal, N. (2014). Karakterisasi dan Potensi Pemanfaatan Limbah Sawit. ITENAS, Bandung.

Menteri Lingkungan Hidup Republik Indonesia. (2003). Keputusan Menteri Lingkungan Hidup Nomor: 115 Tahun 2003 tentang Pedoman Penentuan Status Mutu Air, Jakarta: Departemen Lingkungan Hidup 